\title{
Poor bioavailability of vitamin D2 from ultraviolet-irradiated D2-rich yeast in rats
}

\section{Itkonen, Suvi T.}

2018-11

Itkonen , S T, Pajula , E T, Dowling , K G , Hull , G L J , Cashman , K D \& Lamberg-Allardt , C J E 2018 , ' Poor bioavailability of vitamin D 2 from ultraviolet-irradiated D 2 -rich yeast in rats ' , Nutrition Research , vol. 59 , pp. 36-43 . https://doi.org/10.1016/j.nutres.2018.07.008

http://hdl.handle.net/10138/311144

https://doi.org/10.1016/j.nutres.2018.07.008

cc_by_nc_nd

acceptedVersion

Downloaded from Helda, University of Helsinki institutional repository.

This is an electronic reprint of the original article.

This reprint may differ from the original in pagination and typographic detail.

Please cite the original version. 
3 Title: Poor bioavailability of vitamin $D_{2}$ from $U V$-irradiated $D_{2}$-rich yeast in rats 4

5 Authors: Suvi T Itkonen ${ }^{a}$, Elina T Pajula ${ }^{a}$, Kirsten G Dowling ${ }^{\text {b }}$, George LJ Hull ${ }^{\text {, }}$, Kevin 6 D Cashman ${ }^{\mathrm{b}, \mathrm{c}}$, Christel JE Lamberg-Allardt ${ }^{\mathrm{a}}$

7

8 Author affiliations: ${ }^{\mathrm{a} C a l c i u m}$ Research Unit, Department of Food and Nutrition, University

9 of Helsinki, Helsinki, Finland, ${ }^{b}$ Cork Centre for Vitamin D and Nutrition Research, School of 10 Food and Nutritional Sciences, University College Cork, Cork, Ireland, 'Department of

11 Medicine, University College Cork, Cork, Ireland

12

13 Contact information of the authors: STI suvi.itkonen@ helsinki.fi, ETP

14 elina.t.pajula@gmail.com, KGD granumk@yahoo.com, GLJH george.hull@teagasc.ie, KDC 15 k.cashman@ucc.ie, CJELA christel.lamberg-allardt@helsinki.fi

Corresponding author:

Christel J. E. Lamberg-Allardt

Address: Calcium Research Unit, Department of Food and Nutrition, University of Helsinki,

P. O. Box 66, 00014 University of Helsinki, Helsinki, Finland

Email: christel.lamberg-allardt@helsinki.fi

Tel. +358-40-5769500 


\section{Abbreviations page}

27

28

29

\section{Abbreviations}

30

31

32 BMC; bone mineral content

33 BMD; bone mineral density

$34 \mathrm{CV}$; coefficient of variation

35 CYP24A1; cytochrome P24A1

36 DXA; dual-energy X-ray bone densitometry

$37 \quad \mathrm{D}_{2}$; vitamin $\mathrm{D}_{2}$

$38 \mathrm{D}_{3}$; vitamin $\mathrm{D}_{3}$

39 LC-MS/MS; liquid chromatography-tandem mass spectrometry

$40 \mathrm{SD}$; standard deviation

41 SE; standard error

42 S-PTH; serum parathyroid hormone

43 S-Ca; serum calcium

$44 \quad \mathrm{~S}-\mathrm{Pi}$; serum phosphate

$45 \mathrm{UV}$; ultraviolet

$46 \quad 1,25(\mathrm{OH})_{2} \mathrm{D} ; 1,25$-dihydroxyvitamin $\mathrm{D}$

$4724,25(\mathrm{OH})_{2} \mathrm{D} ; 24,25$-dihydroxyvitamin $\mathrm{D}$

$48 \quad 25(\mathrm{OH}) \mathrm{D} ; 25$-hydroxyvitamin D

49

50 


\section{Abstract page}

52

53

54

55

56

57

58

59

60

61

62

63

64

65

66

67

68

69

70

71

72

73

74 Keywords: Bioavailability; Biofortification; Rats; UV-irradiated yeast; Vitamin $\mathrm{D}_{2} ; 25$ -

75 hydroxyvitamin D

products with vitamin $\mathrm{D}$, but in bread it was not effective in increasing serum 25-

hydroxyvitamin $\mathrm{D}(25(\mathrm{OH}) \mathrm{D})$ in humans, possibly due to the low digestibility of the yeast matrix. We investigated the effects of vitamin $\mathrm{D}_{2}$-rich intact yeast cells and their separated fraction, yeast cell walls, which we hypothesized to provide vitamin $\mathrm{D}_{2}$ in a more bioavailable form, on serum 25(OH)D and its metabolites in growing female Sprague Dawley rats $(n=54)$ compared to vitamin $\mathrm{D}_{2}$ and $\mathrm{D}_{3}$ supplements (eight treatment groups: 300 or 600 IU vitamin $\mathrm{D} / \mathrm{d}$, and a control group, 8 week intervention). The $\mathrm{D}_{3}$ supplement groups had the highest 25(OH)D concentrations, and the vitamin $\mathrm{D}_{2}$ supplement at the $600 \mathrm{IU}$ dose increased 25(OH)D better than any yeast form $(\mathrm{P}<0.001$ for all, analysis of covariance, adjusted for body weight). There were no significant differences between the yeast forms at the same dose ( $\mathrm{P}>0.05)$. Serum 24,25-dihydroxyvitamin $\mathrm{D}\left(24,25(\mathrm{OH})_{2} \mathrm{D}\right.$; a vitamin D catabolite) concentrations and the trend in the differences between the groups were in line with $25(\mathrm{OH}) \mathrm{D}$ ( $\mathrm{P}<0.001$ for all). The $24,25(\mathrm{OH})_{2} \mathrm{D}$ to $25(\mathrm{OH}) \mathrm{D}$ ratio between the $\mathrm{D}_{2}$ supplement and the yeast groups did not differ $(\mathrm{P}>0.05)$. These findings do not support the hypothesis: the ability of the different UV-treated vitamin $\mathrm{D}_{2}$-containing yeast forms to increase $25(\mathrm{OH}) \mathrm{D}$ did not differ and the poor bioavailability of vitamin $D_{2}$ in the yeasts compared $D_{3}$ or $D_{2}$ supplements could not be explained by the increased vitamin D catabolism in the yeast-treated groups.

73 
Due to the limited selection of naturally vitamin D-rich food sources, food fortification with vitamin D has been considered a viable option to improve vitamin D intake in the population [1]. While still debated, vitamin $\mathrm{D}_{3}$ may be more potent than vitamin $\mathrm{D}_{2}$ in terms of

81

87 increasing serum 25-hydroxyvitamin D [25(OH)D, widely regarded as an index of vitamin D status] concentration [2]. Although most vitamin D-fortified foods are enriched with animaloriginated vitamin $\mathrm{D}_{3}$, vitamin $\mathrm{D}_{2}$ may have other advantages such as its commercial production can be very cost-effective and it is suitable also for use in strict vegetarians [3]. For these reasons vitamin $\mathrm{D}_{2}$ has potential for broader utilization in food fortification.

In addition to the traditional mode of fortification, in which vitamin D is exogenously added to the product, the vitamin D contents of the foodstuffs can be increased by biofortification means [4]. Amongst others, this can include the ultraviolet (UV) B irradiation of fungi i.e. mushrooms or baker's yeast [5]. UV-irradiated yeast, with enhanced vitamin $\mathrm{D}_{2}$ levels, can be used to enrich bakery products with vitamin D: irradiated yeast cells retain most of their gassing power which makes them ideal for enrichment of yeast leavened products, such as bread [6]. Hohman et al [7] studied a bread made with UV-treated, vitamin $\mathrm{D}_{2}$-rich yeast in vitamin D-deficient rats, and vitamin $\mathrm{D}_{2}$ from yeast was shown to be bioavailable, although not as effective in increasing plasma $25(\mathrm{OH}) \mathrm{D}$ concentrations as a vitamin $\mathrm{D}_{3}$ supplement. Later, Itkonen and coworkers [8] investigated the bioavailability of vitamin $\mathrm{D}_{2}$ from bread baked with UV-treated yeast in an 8-week winter-based randomized controlled trial in young healthy women. Consumption of bread produced with the UV-treated, vitamin $\mathrm{D}_{2}$-rich yeast did not increase total $25(\mathrm{OH}) \mathrm{D}$ concentration, while women given bread made with regular 
101

yeast and either a vitamin $\mathrm{D}_{2}$ or $\mathrm{D}_{3}$ supplement (providing the same level of vitamin $\mathrm{D}$ as $\mathrm{D}_{2}$ enriched bread) had significant improvements in total $25(\mathrm{OH}) \mathrm{D}$ concentration. Interestingly, Lipkie et al [9] recently utilized their in vitro bioaccessibility model, which simulated digestion in the gastrointestinal tract after ingestion of UV-yeast fortified bread, and found that intact yeast cells were present in the digesta of the yeast fortified bread. These findings suggest a low bioaccessibility of vitamin $\mathrm{D}_{2}$ in this UV-treated yeast, due to the lower digestibility of the yeast matrix. This may explain the findings of low bioavailability of the vitamin $\mathrm{D}_{2}$ from the bread used in the study of Itkonen et al. [8]. It is worth noting that UVirradiated $\mathrm{D}_{2}$-rich yeast is already used in some breads on the market and despite its vitamin $\mathrm{D}$ content, could be a poor source of bioavailable vitamin D.

Due to the matrix effects it is possible that the bioavailability of the $\mathrm{D}_{2}$ in yeast, and thus the ability to increase serum $25(\mathrm{OH}) \mathrm{D}$, may be better if a separate cell wall fraction of the yeast is used. In that case, the matrix is already broken because the yeast cell walls are separated from the intact yeast cells by autolysis or hydrolysis and centrifugation [10]. Therefore, we hypothesize that yeast cell wall fraction due to potentially better bioavailability of its $\mathrm{D}_{2}$ may be more capable of improving vitamin D status than the intact yeast cells. Accordingly, we investigated the ability of vitamin $\mathrm{D}_{2}$-rich intact yeast cells (Saccharomyces cerevisiae) and yeast cell walls to increase serum $25(\mathrm{OH}) \mathrm{D}$ in growing rats compared to vitamin $\mathrm{D}_{2}$ and $\mathrm{D}_{3}$ supplements. In addition, to discount the possibility that vitamin $\mathrm{D}_{2}$ from the UV-treated yeast is metabolized more rapidly than supplemental vitamin $\mathrm{D}_{2}$, the concentration of the 24pathway degradation metabolite, 24,25-dihydroxyvitamin $\mathrm{D}\left(24,25(\mathrm{OH})_{2} \mathrm{D}\right)$ was also assessed. The effects of the different forms of vitamin D on bone development within the growing rats were examined by measuring femoral bone mineral content (BMC), bone area, 
141

144 Three-week old, Sprague Dawley ${ }^{\circledR}$ Outbred female rats $(n=54)$ were obtained from Harlan and bone mineral density (BMD). Finally, additional information about vitamin D-related metabolism and safety of the different vitamin D sources was obtained by measuring calcium metabolism biomarkers in serum.

\section{Methods and materials}

\subsection{Ethical approval}

\subsection{Animals and feeds}

145 Laboratories (Madison, WI, USA). They were placed in the Laboratory Animal Centre of the

146 University of Helsinki and cared for by its personnel. The light/dark cycle was 12 hours and

147 water was provided ad libitum. The animals were allowed to acclimatize one week prior the

148 study. During this acclimatization period, the rats were fed with Teklad global $16 \%$ protein 149 rodent diet (2916C-031015MA, Harlan Laboratories, Madison, WI, USA). For the 150 experimental period, the rats were stratified into nine groups of six animals each. All diets 
151 were obtained from Harlan laboratories (Madison, WI, USA). The basis of each diet was the

152 AIN-93G diet (recommended for growing rodents) with vitamin-free tested casein (TD.

153 07669). The diets of the nine groups varied by the amount and source of vitamin D: control

154 diet and diets containing one of two different doses of vitamin D (300 IU/d or $600 \mathrm{IU} / \mathrm{d})$ and

155 as either vitamin $\mathrm{D}_{3}$ supplement, vitamin $\mathrm{D}_{2}$ supplement, vitamin $\mathrm{D}_{2}$-rich intact yeast cells or

156 vitamin $\mathrm{D}_{2}$-rich yeast cell walls. The diets are described in detail in Table 1 . The maximum

157 food consumption was estimated to be 20 grams per day which was provided daily, and the

158 excess food was weighted after the experiment.

159

160

161 Supplemental vitamin $\mathrm{D}_{3}$ was provided by Harlan Laboratories, whereas supplemental

162 vitamin $\mathrm{D}_{2}$ was obtained from Sigma-Aldrich (Ergocalciferol, 40000000 USP units/g,

163 E5750, CAS 50-14-6, EC 200-014-9, St. Louis, MO, USA). The yeasts were provided by

164 LALLEMAND Inc. (Montreal, Canada). The production process for the UV-irradiated $\mathrm{D}_{2}-$ rich yeast preparations is described elsewhere $[6,10]$. The $\mathrm{D}_{2}$ supplements and the yeasts preparations were shipped to Harlan Laboratories where the diets were produced. The exact

167

168

169

170

171

172

173

174

175

vitamin D contents of LALLEMAND yeasts were analyzed by Covance (Princeton, NJ, USA) by high-performance liquid chromatography [11]. The amount of $\mathrm{D}_{3}$ in the $\mathrm{D}_{2}$ diets was below the detection limit of $20 \mu \mathrm{g} / 100 \mathrm{~g}$. The vitamin $\mathrm{D}_{2}$ contents of the spray-dried intact yeast cells and yeast cell walls were 39,250 $\mu \mathrm{g} / 100 \mathrm{~g}(1,570,000 \mathrm{IU})$ and 138,500 $\mu \mathrm{g} / 100 \mathrm{~g}(5,540,000$

$$
\text { IU), respectively. }
$$

\subsection{Experiments}


177 The experimental period was for eight weeks during which the rats were allowed to feed ad

178 libitum. Each rat was weighted every two weeks (i.e., at 0, 2, 4, 6 and 8 weeks) within the

179 experimental period, when the rats were 4, 6, 8, 10 and 12 weeks of age, respectively. After

180 eight weeks, the rats were euthanized with $\mathrm{CO}_{2}$ and their necks were broken. Blood was

181 drawn by cardiac puncture and centrifuged soon after drawing. The serum samples were

182 stored at $-70^{\circ} \mathrm{C}$ until required for analyses.

183

184

185

2.4 Biochemical analyses

186

187

188

Serum $25(\mathrm{OH}) \mathrm{D}_{3}, 25(\mathrm{OH}) \mathrm{D}_{2}, 24,25(\mathrm{OH})_{2} \mathrm{D}_{3}$ and $24,25(\mathrm{OH})_{2} \mathrm{D}_{2}$ concentrations were analyzed

189

by the Cork Centre for Vitamin D and Nutrition Research at University College Cork in

190

Ireland using a liquid chromatography-tandem mass spectrometry (LC-MS/MS) method,

191 modified from a validated method for the analysis of $25(\mathrm{OH}) \mathrm{D}_{3}, 25(\mathrm{OH}) \mathrm{D}_{2}$, and

$19224,25(\mathrm{OH})_{2} \mathrm{D}_{3}[12]$. Total $25(\mathrm{OH}) \mathrm{D}$ and $24,25(\mathrm{OH})_{2} \mathrm{D}$ concentrations were calculated as

$193\left[25(\mathrm{OH}) \mathrm{D}_{3}+25(\mathrm{OH}) \mathrm{D}_{2}\right]$, and $\left[24,25(\mathrm{OH})_{2} \mathrm{D}_{3}+24,25(\mathrm{OH})_{2} \mathrm{D}_{2}\right]$, respectively. The

194 quantification range (nmol/L) was $2.52-323$ for $25(\mathrm{OH}) \mathrm{D}_{3}, 1.31-168$ for $25(\mathrm{OH}) \mathrm{D}_{2}, 0.72-185$

195 for $24,25(\mathrm{OH}) \mathrm{D}_{3}$, and $0.69-176$ for $24,25(\mathrm{OH}) \mathrm{D}_{2}$. The $\mathrm{CV}(\%)$ for all metabolites was $<10 \%$.

196 Further details of the serum extraction and LC-MS/MS analysis can be found in the

197 Supplementary material.

198

199 
200 Serum parathyroid hormone (S-PTH) concentrations were analyzed by enzyme-labeled

201 immunometric assay with the Rat Intact PTH ELISA Kit (Immutopics Inc., San Clemente,

202 CA, USA) at the Department of Food and Nutrition, University of Helsinki [13]. Due to the

203 heterogeneity of the S-PTH results, the analyses were carried out in duplicate, however, the

204 results were consistent. Serum calcium (S-Ca) and serum phosphate (S-Pi) concentrations

205 were analyzed by a spectrophotometric method by Konelab20 automatic analyser (Thermo

206 Clinical Labsystems Oy, Espoo, Finland) at the Department of Food and Nutrition, University

207 of Helsinki $[14,15]$. The inter- and intra-assay CV (\%) for S-Ca and S-Pi were $<4.6 \%$ and

$208<4.6 \%$, respectively.

209

210

211

2.5 Bone measurements (femoral bone area, BMC and BMD)

212

213

214 Left hind legs were excised within a few hours following kill, using scissors and scalpels.

215 Immediately after removal, femoral bone area $\left(\mathrm{cm}^{2}\right), \mathrm{BMC}(\mathrm{g})$ and $\mathrm{BMD}\left(\mathrm{g} / \mathrm{cm}^{2}\right)$ were measured with a dual-energy X-ray bone densitometry device (DXA) (Lunar Piximus, GE Healthcare, Little Chalfont, UK) [16]. Because the whole leg was measured, the region of interest needed to be adjusted manually to cover only the femur. Prior to measurement, a quality control check was performed using a phantom mouse as per DXA supplier instructions.

221

222

223

\subsection{Statistical analyses}

224 
226 The choice of number of animals per treatment group in the present study was informed by

227 data on the average number of animals used in cognate vitamin D feeding studies in rats

$228[17,18]$. In addition, post hoc sample size calculations showed that the number of rats per

229 group was sufficient to show significant differences (at an alpha of 0.05 and $80 \%$ power) in

230 serum total $25(\mathrm{OH}) \mathrm{D}$, as the priority outcome measure, between the different vitamin $\mathrm{D}$ forms

231 when compared at a similar dose level.

232

233

234 Data are presented in tables as means \pm standard deviation (SD), and in figures as means \pm standard error (SE). The normality and homogeneity of the data were verified and logtransformed to improve normality, when needed. All tests were considered significant at $P<0.05$. Differences between the treatment groups were studied by one-way analysis of variance and analysis of covariance using rat body weight at the end of the intervention as a covariate. Post hoc tests for the differences between the groups were carried out with Fisher's least significant difference test. Spearman correlation coefficients were used to test for significant associations between vitamin $\mathrm{D}$ metabolites and bone measurements for all rats, and separately according to the vitamin $\mathrm{D}$ source $\left(\mathrm{D}_{3}\right.$ or $\left.\mathrm{D}_{2}\right)$. Statistical analysis was performed by SPSS Statistics version 23 (IBM, Armonk, NY, USA).

\section{Results}


Descriptive statistics of the vitamin D intake and rat body weight are described in the Table 2 .

When excess food was weighted after the experiment, the actual daily vitamin D intake was lower than excepted (Table 2).

255

256

257

258

259

260

261

262

263

264

265

266

267

268

269

270

271

272

\subsection{Serum 25(OH)D concentrations}

There was no trace of $25(\mathrm{OH}) \mathrm{D}_{2}$ in serum of animals fed supplemental vitamin $\mathrm{D}_{3}$, nor $25(\mathrm{OH}) \mathrm{D}_{3}$ in serum of animals fed supplemental vitamin $\mathrm{D}_{2}$ (data not shown). Statistically significant differences in serum total $25(\mathrm{OH}) \mathrm{D}$ concentration were found between the study groups $(\mathrm{P}<0.001$, Figure $1 \mathrm{~A})$. Serum total $25(\mathrm{OH}) \mathrm{D}$ in the control group was lower than in all other groups $(\mathrm{P}<0.001-0.005)$, with the exception of the lower dose intact yeast cell group ( $\mathrm{P}>0.05)$. The higher vitamin $\mathrm{D}_{3}$ dose group differed from all other groups $(\mathrm{P}<0.001)$, whereas the lower vitamin $\mathrm{D}_{3}$ dose group differed from all other groups $(\mathrm{P}<0.001-0.002)$, except from the higher dose vitamin $\mathrm{D}_{2}$ group $(\mathrm{P}>0.05)$ : vitamin $\mathrm{D}_{3}$ supplement-fed groups had the highest serum total $25(\mathrm{OH}) \mathrm{D}$ concentrations post intervention. At the lower dose level (300 IU/d), feeding the vitamin $\mathrm{D}_{2}$ supplement resulted in higher serum total $25(\mathrm{OH}) \mathrm{D}$ than feeding with intact yeast cells $(\mathrm{P}=0.026)$, but no differences compared to cell wall were evident $(\mathrm{P}>0.05)$. However, at the higher dose level (600 IU/d), the vitamin $\mathrm{D}_{2}$ group had a higher serum total $25(\mathrm{OH}) \mathrm{D}$ than either of the yeast forms $(\mathrm{P}=0.002-0.020)$. There were 
statistical differences evident between the intact yeast cell and cell wall fraction groups when

274 compared at the same dose levels $(\mathrm{P}>0.05)$.

275

276

277

\subsection{Serum $24,25(\mathrm{OH})_{2} \mathrm{D}$ concentrations and $24,25(\mathrm{OH})_{2} \mathrm{D}$ to $25(\mathrm{OH}) \mathrm{D}$ ratio}

Serum $24,25(\mathrm{OH})_{2} \mathrm{D}$ correlated well with total $25(\mathrm{OH}) \mathrm{D}$ (Supplemental Table). Differences in

281

282

283

284

285

286

287

288

289

290

291

292

293

294

295 to 1.14 .

serum $24,25(\mathrm{OH})_{2} \mathrm{D}$ and $24,25(\mathrm{OH})_{2} \mathrm{D}$ to $25(\mathrm{OH}) \mathrm{D}$ ratio were significant between the groups

(P for both <0.001) (Figures 1B, 1C). All treatment groups had higher serum 24,25(OH) $)_{2} \mathrm{D}$ concentrations than the control group $(\mathrm{P}<0.001-0.015)$, and higher doses of each vitamin $\mathrm{D}$ form resulted in higher serum $24,25(\mathrm{OH})_{2} \mathrm{D}$ concentrations compared to the lower dose $(\mathrm{P}=0.001-0.041)$. Highest serum concentrations were present in higher dose vitamin $\mathrm{D}_{3}$ group $(\mathrm{P}<0.001-0.037)$ while vitamin $\mathrm{D}_{2}$ and cell wall groups were on similar level and did not differ from each other $(\mathrm{P}>0.05)$. The intact yeast cell groups had the lowest serum $24,25(\mathrm{OH})_{2} \mathrm{D}$ concentrations: the lower dose group differed significantly from all other groups $(\mathrm{P}<0.001-0.039)$, except from the lower dose $\mathrm{D}_{2}$ supplement group $(\mathrm{P}>0.05)$, and the higher dose differed from all other groups $(\mathrm{P}<0.001-0.016)$, except from the cell wall groups ( $\mathrm{P}>0.05)$. Concerning the $24,25(\mathrm{OH})_{2} \mathrm{D}$ to $25(\mathrm{OH}) \mathrm{D}$ ratio, with the exception of the high dose vitamin $\mathrm{D}_{3}(0.79 ; \mathrm{P}>0.05)$, all other groups had a higher ratio than control $(0.69)(\mathrm{P}<0.001-$ 0.002). Higher dose $\mathrm{D}_{3}$ differed from the other treatment groups $(\mathrm{P}<0.001-0.033)$. The ratios between other groups or doses did not differ from each other $(\mathrm{P}>0.05)$ and ranged from 1.00 
There were no significant differences in mean body weights between the groups at the end of the intervention (Table 2). There were no significant correlations between bone parameters and serum total 25(OH)D (Supplemental Table), but bone area and BMC correlated negatively with $24,25(\mathrm{OH})_{2} \mathrm{D}$ to $25(\mathrm{OH}) \mathrm{D}$ ratio when all rats were pooled, and a negative correlation between bone area and $24,25(\mathrm{OH})_{2} \mathrm{D}$ to $25(\mathrm{OH}) \mathrm{D}$ among vitamin $\mathrm{D}_{2}$ treated rats was also evident. In bone area and BMC tended to be differences between the treatment groups $(\mathrm{P}=0.068$ and $\mathrm{P}=0.069$, respectively) (Figures $1 \mathrm{D}, 1 \mathrm{E})$. The adjusted mean values of bone area and $\mathrm{BMC}$ tended to be highest in the higher dose vitamin $\mathrm{D}_{3}$ group followed by the lower dose vitamin $\mathrm{D}_{3}$ and higher dose cell wall groups. There were no significant differences evident in mean $\mathrm{BMD}$ values $(\mathrm{P}=0.127)$ (Figure $1 \mathrm{~F})$.

311

312

\subsection{Calcium metabolism biomarkers}

S-PTH correlated positively with $25(\mathrm{OH}) \mathrm{D}$ and $24,25(\mathrm{OH})_{2} \mathrm{D}$ when all rats were pooled. In vitamin $\mathrm{D}_{3}$ treated rats significant positive correlations between S-PTH and $24,25(\mathrm{OH})_{2} \mathrm{D}$, $\mathrm{BMC}$ and bone area were evident, but not among vitamin $\mathrm{D}_{2}$ treated rats. Significant differences in S-Pi and S-PTH concentrations between the high vitamin $\mathrm{D}_{3}$ dose and all other groups were seen $(\mathrm{P}=0.001$ for both), but no differences between intact yeast cell and cell wall groups were present for either marker (Figures $1 \mathrm{G}, 1 \mathrm{H}$ ). However, results from S-PTH assay showed great deviation within some groups. There were four animals with S-PTH 
323

324

325

326

327

328

329

330

331

332

333

334

335

336

337

338

339

340

341

342

343

344

345

346

347

concentration higher than $2000 \mathrm{pg} / \mathrm{mL}$, three of which belong to group fed with higher

vitamin $\mathrm{D}_{3}$ supplement dose and the remaining one to group fed with smaller vitamin $\mathrm{D}_{3}$ dose. In the other groups, the variation was smaller. No differences in S-Ca concentration between the groups were present $(\mathrm{P}=0.640$, Figure 1I).

\section{Discussion}

In the present study of growing female Sprague Dawley rats, the vitamin D bioavailability and safety of UV-irradiated vitamin $\mathrm{D}_{2}$-rich intact yeast cells and their cell wall fraction in different doses were examined. Calcium metabolism biomarker data in the present study suggested both yeast forms were seen to be safe. The study showed that while both vitamin $\mathrm{D}_{2}$ and vitamin $\mathrm{D}_{3}$ were capable in increasing serum total $25(\mathrm{OH}) \mathrm{D}$, all vitamin $\mathrm{D}_{2}$-diets showed lower effectiveness in terms of raising serum total $25(\mathrm{OH}) \mathrm{D}$ compared to supplemental vitamin $\mathrm{D}_{3}$, at both dose levels. These vitamer-specific findings in young rats are very much in keeping with recent studies in humans. For example, Tripkovic et al. [2] in their systematic review showed that vitamin $\mathrm{D}_{3}$ was more effective in increasing $25(\mathrm{OH}) \mathrm{D}$ concentrations than vitamin $\mathrm{D}_{2}$.

In terms of bioavailability, vitamin $\mathrm{D}_{2}$-rich yeast used in the present study as intact yeast cells (supplying vitamin D at the 300 IU dose level) and yeast cell walls (at 300 and 600 IU dose levels) were effective in increasing serum total $25(\mathrm{OH}) \mathrm{D}$ compared to control, even if for the most part were less effective than the vitamin $\mathrm{D}_{2}$ supplement. Similarly, Hohman et al. [7] in 
their earlier study of vitamin D-deficient rats, observed that vitamin $\mathrm{D}_{2}$ from $\mathrm{UV}$-irradiated yeast was bioavailable, but not as effective at increasing plasma $25(\mathrm{OH}) \mathrm{D}$ concentration as vitamin $\mathrm{D}_{3}$. It should be noted, however, they did not use a vitamin $\mathrm{D}_{2}$ supplement as a positive control. Furthermore, Hohman and coworkers used vitamin D-deprived animals in their study [7]. This may be of consequence, as it has been seen in human studies that individuals with the lowest baseline $25(\mathrm{OH}) \mathrm{D}$ concentrations have the strongest response to increased vitamin D intake [19]. The estimated levels of ingested vitamin D in the present study, even though the dietary levels were lower than excepted, were approximately 20 -fold higher than the recommended daily intake for growing rats $[17,18]$. Thus, the rats were of adequate vitamin D status. Of note, in their 8-week, winter-based intervention study of young healthy women in Finland, Itkonen et al [8] showed that consumption of bread produced with the UVB-treated, vitamin $\mathrm{D}_{2}$-rich intact yeast failed to lead to an increase in serum total $25(\mathrm{OH}) \mathrm{D}$ concentration, even though a significant increase in serum total $25(\mathrm{OH}) \mathrm{D}$ was

361 evident in the women receiving bread made with regular yeast and either a vitamin $\mathrm{D}_{2}\left(\right.$ or $\left.\mathrm{D}_{3}\right)$ supplement. Likewise, in our study, the lower dose of intact yeast cells was not able to increase serum total 25(OH)D compared to the control group. Lipkie et al [9] have demonstrated using their in vitro digestion model that the main problem is the yeast matrix that is not broken down liberating the vitamin $\mathrm{D}_{2}$ for intestinal absorption. The present study also used yeast cell wall to try and counteract this matrix effect and overcome the lower bioavailability. However, our results suggest vitamin $\mathrm{D}_{2}$ from the yeast cell wall fraction did not have much better bioavailability than vitamin $\mathrm{D}_{2}$ from the intact yeast cells.

We wished to discount the possibility that the lack of increase of serum total $25(\mathrm{OH}) \mathrm{D}$ in the young women in the Itkonen et al [8] study who received bread made with UV-treated intact 
yeast, was due to enhanced catabolism of $25(\mathrm{OH}) \mathrm{D}$. Thus, we measured serum $24,25(\mathrm{OH}) \mathrm{D}_{2}$

374 and its ratio to $25(\mathrm{OH}) \mathrm{D}$ in the rats in all nine groups as indices of vitamin D catabolism.

375

376

377

378

379

380

381

382

383

384

385

386

387

388

389

390

391

392

393

394

395

396

397

$24,25(\mathrm{OH}) \mathrm{D}_{2}$ is the first catabolite of $25(\mathrm{OH}) \mathrm{D}$ arising from its hydroxylation by cytochrome P24A1 (CYP24A1) [20]. In the present study of young growing rats, the $24,25(\mathrm{OH})_{2} \mathrm{D}$ was associated with $25(\mathrm{OH}) \mathrm{D}$ concentrations: the more vitamin $\mathrm{D}$ ingested, the higher the concentrations of $25(\mathrm{OH}) \mathrm{D}$ and the catabolite in serum (in line with that observed in humans [21]). Furthermore, the trend in the differences was similar to that seen in $25(\mathrm{OH}) \mathrm{D}$. The ratio of $24,25(\mathrm{OH})_{2} \mathrm{D}$ to $25(\mathrm{OH}) \mathrm{D}$ depends on the activity of CYP24A1, and it has been suggested to be a better marker of vitamin D status than only $25(\mathrm{OH}) \mathrm{D}$, as it seems to be an indicator of vitamin D deficiency [20]. The concentration of $24,25(\mathrm{OH})_{2} \mathrm{D}$ in humans usually ranges from 2 to $20 \%$ of total $25(\mathrm{OH}) \mathrm{D}$ [21]. In the present study, however, the proportions in rats were much higher, the values ranging from 69 to $114 \%$, suggesting difference in vitamin D metabolism in rats. Interestingly, the lowest ratios were present in the control group and higher dose vitamin $\mathrm{D}_{3}$ group, which may indicate that less vitamin D is "wasted" with higher dose of vitamin $\mathrm{D}_{3}$ whereas no differences were present between different vitamin $\mathrm{D}_{2}$ sources. However, this does not explain the results of the control group. While acknowledging possible species differences in absolute concentration of $24,25(\mathrm{OH})_{2} \mathrm{D}$, and its ratio to $25(\mathrm{OH}) \mathrm{D}$, that these were not higher in the yeast-treated groups compared to vitamin $\mathrm{D}_{2}$ supplement rat groups, might suggest that the observed differences in serum total $25(\mathrm{OH}) \mathrm{D}$ between the yeast-derived vitamin $\mathrm{D}_{2}$ and vitamin $\mathrm{D}_{2}$ supplement groups in the human trial of Itkonen et al [8] were not due to the increased catabolism, but more likely as a consequence of low bioavailability of the vitamin $\mathrm{D}_{2}$ from yeast. However, this issue of poor bioavailability of vitamin $\mathrm{D}_{2}$ from UV-treated foods, seems not to be the case for UV-treated mushrooms. For example, in a rat study with high vitamin D doses in the form of UV-treated mushrooms, Calvo et al [18] found that these mushrooms were effective in increasing plasma 
total $25(\mathrm{OH}) \mathrm{D}$. Yet, the study also lacked of a vitamin $\mathrm{D}_{2}$ or $\mathrm{D}_{3}$ control. UVB-treated

399 mushrooms, as well the wild mushrooms exposed to UV sunlight, have been shown to be as

400

401

402

403

404

405

406

407

408

409

410

411

412

413

414

415

416

417

418

419 420 findings.

effective as $\mathrm{D}_{2}$ supplement in increasing serum total 25(OH)D in humans [22,23].

In our study, bone area and BMC tended to be higher in the vitamin $\mathrm{D}_{3}$ treated groups than in other groups. This may indicate the positive effect of vitamin $\mathrm{D}_{3}$ supplementation on bone development, as seen in earlier rat studies [24,25]. However, recently Chun et al [26] found that vitamin $\mathrm{D}_{2}$ treated mice had higher bone volume/total volume and trabecular number and thickness than vitamin $\mathrm{D}_{3}$ treated mice. They also found higher free $25(\mathrm{OH}) \mathrm{D}$ concentrations in vitamin $\mathrm{D}_{2}$ fed animals. Free $25(\mathrm{OH}) \mathrm{D}$ has been suggested to be a one of the better alternative measures to describe the active, bioavailable part of $25(\mathrm{OH}) \mathrm{D}$ and thus vitamin $\mathrm{D}$ status $[27,28]$. Free $25(\mathrm{OH}) \mathrm{D}$ has been shown to correlate better than total $25(\mathrm{OH}) \mathrm{D}$ with health outcomes such as bone parameters in humans [28]. Unfortunately, in the current study we did not have data on free $25(\mathrm{OH}) \mathrm{D}$. Concerning calcium metabolism markers, while there were no significant differences in S-Ca, unexpectedly both S-Pi and S-PTH were elevated in vitamin $\mathrm{D}_{3}$-treated groups. Usually $25(\mathrm{OH}) \mathrm{D}$ and S-PTH concentrations correlate inversely [29] but in our study the correlation was positive. The extremely high S-PTH concentrations in high dose vitamin $\mathrm{D}_{3}$ group may be a consequence of the increased $\mathrm{S}-\mathrm{Pi}$, interplaying with the active metabolite of vitamin $\mathrm{D}$, serum 1,25-dihydroxyvitamin $\mathrm{D}\left(1,25(\mathrm{OH})_{2} \mathrm{D}\right)$ [30]. On the other hand, S-PTH concentrations showed notable within group variations, even though analysis was performed in duplicate, and this needs to be borne in mind when interpreting the

421

422 
The present study used LC-MS/MS technology to measure $25(\mathrm{OH}) \mathrm{D}_{2}$ and $25(\mathrm{OH}) \mathrm{D}_{3}$ to

424

425

426

427

428

429

430

431

432

433

434

435

436

437

438

439

440

441

442

443

444

445

446

447 generate a serum total $25(\mathrm{OH}) \mathrm{D}$ as well as $24,25(\mathrm{OH})_{2} \mathrm{D}_{2 / 3}$ as an index of vitamin $\mathrm{D}$

catabolism, which was a particular strength. However, the study is not without limitations.

Small group sizes might have reduced the statistical significance of the experiment regarding

the bone parameters, but these were secondary outcome measures. Furthermore, a longer

duration would have provided more information about the long-term exposure to high vitamin

$\mathrm{D}$ intake and the toxicity. It is also possible that there would have been differences in measured bone parameters if the rats have been allowed to reach the skeletal maturity.

Moreover, the blood samples were taken only in the end of the intervention. The baseline information could have offered interesting data on changes in total $25(\mathrm{OH}) \mathrm{D}$ and other metabolites. It is also possible that inclusion of vitamin D-deficient rats in the present study, may have led to greater differences in bioavailability between the different vitamin D forms. Further, analysis of free and bioavailable $25(\mathrm{OH}) \mathrm{D}$ as well as $1,25(\mathrm{OH})_{2} \mathrm{D}$ could have provided more explanation to the remaining open questions about the bioavailability of the different yeast forms.

In conclusion, the present study in young growing rats did not find major differences between UV-treated vitamin $\mathrm{D}_{2}$-rich intact yeast cells or the cell wall fraction in terms of their capacity for increasing total serum $25(\mathrm{OH}) \mathrm{D}$, and our findings do not support the hypothesis that the cell wall fraction might be more capable of improving vitamin D status compared to the intact yeast cells. Further, the yeast forms were less potent in increasing serum total 25(OH)D than vitamin $\mathrm{D}_{3}$ or higher dose vitamin $\mathrm{D}_{2}$ supplements. These vitamin $\mathrm{D}$ status results could not be explained by the increased vitamin D catabolism in the yeast treated groups, where the concentrations of $24,25(\mathrm{OH})_{2} \mathrm{D}$ were similar to or lower than the vitamin $\mathrm{D}_{2}$ supplement- 
treated groups. In the light of the present knowledge, UV-treated vitamin $\mathrm{D}_{2}$-rich yeast could

449 only be recommended as a minor option in terms of a food fortificant until further

450 investigations ascertain the bioavailability of different yeast preparations.

451

452

453

Acknowledgment

454

455

456 We thank the personnel at Laboratory Centre of the University of Helsinki for taking care of

457 the rats and the technician Anu Heiman-Lindh at the Department of Food and Nutrition of the

458 University of Helsinki for her input to the practical work of the study. This work was

459 supported by Lallemand SAS and Medicinska Understödsförening Liv och Hälsa. The funders

460 had no role in the design, implementation, analysis and interpretation of the data. The authors

461 report no conflicts of interest.

462

463

464

465

466

467

468

469

470

471

472 
Black LJ, Seamans KM, Cashman KD, Kiely M. An updated systematic review and meta-analysis of the efficacy of vitamin D food fortification. J Nutr 2012;142:1102-8.

Tripkovic L, Lambert H, Hart K, Smith CP, Bucca G, Penson S, et al. Comparison of vitamin D2 and vitamin D3 supplementation in raising serum 25hydroxyvitamin D status: a systematic review and meta-analysis. Am J Clin Nutr 2012;95:1357-64.

He X, Guo X, Liu N, Zhang B. Ergosterol production from molasses by 484 genetically modified Saccharomyces cerevisiae. Appl Microbiol Biotechnol 485 2007;75:55-60.

Cashman KD, Kiely M. Tackling inadequate vitamin D intakes within the 487 population: fortification of dairy products with vitamin D may not be enough. Endocrine 2016;51:38-46.

Hayes A, Cashman KD. Food-based solution for vitamin D deficiency: putting 490 policy into practice and the key role for research. Proc Nutr Soc 2017;76:54-63. Degre R, Zhang Z, Edwards G. Novel vitamin D2 yeast preparation, a method for 492 producing the same and the use thereof. LALLEMAND Inc. (2008) 12.6.2008. US 2008/0138469 A1.

Hohman EE, Martin BR, Lachcik PJ, Gordon DT, Fleet JC, Weaver CM. Bioavailability and efficacy of vitamin D2 from UV-irradiated yeast in growing, vitamin D-deficient rats. J Agric Food Chem 2011;59:2341-6. 

of vitamin D2-fortified bread versus supplementation with vitamin D2 or D3 on serum 25-hydroxyvitamin D metabolites - an eight-week randomized controlled trial in young adult Finnish women. Br J Nutr 2016;115:1232-9. yeast-fortified bread compared to crystalline D2 bread and D3 from fluid milks. Food Func 2016;7:4589-96.

Degre R, Zhang Z. Yeast cell walls comprising vitamin D2, uses thereof and method of producing the same. LALLEMAND Inc. (2014) 31.7.2014. WO 2014/114342 A1.

Official Methods of Analysis of AOAC INTERNATIONAL. Official Method 982.29,2002.05. (Modified) $18^{\text {th }}$ Ed., AOAC INTERNATIONAL, Gaithersburg, MD, USA; 2005.

Dowling KG, Hull G, Sundvall J, Lamberg-Allardt C, Cashman KD. Improved accuracy of an tandem liquid chromatography-mass spectrometry method measuring 24R,25-dihydroxyvitamin D3 and 25-hydroxyvitamin D metabolites in serum using unspiked controls and its application to determining crossreactivity of a chemiluminescent microparticle immunoassay. J Chrom A 2017;1497:102-9. parathyroid hormone $(\mathrm{PTH})$ concentrations in vivo and in vitro by a 2-site homologous immuno-radiometric assay. Bone Mineral 1994;27:121-132. Burtis CA, Ashwood ER, editors. Tietz Fundamentals of clinical chemistry. $5^{\text {th }}$ Ed. Philadelphia: WB Saunders Company; 2001. p. 797-799,968. 
[15] Burtis CA, Ashwood ER, editors. Tietz Fundamentals of clinical chemistry. $5^{\text {th }}$ Ed. Philadelphia: WB Saunders Company; 2001. p. 802-803.

523

Nagy TR, Clair AL. Precision and Accuracy of Dual-Energy X-ray Absorptiometry for Determining in Vivo Body Composition of Mice Obesity Research 2000;8:392-398.

Fleet JF, Gliniak C, Zhang Z, Xue Y, Smith KB, McCreedy R, et al. Serum metabolite profiles and target tissue gene expression define the effect of cholecalciferol intake on calcium metabolism in rats and mice. $\mathrm{J}$ Nutr 2008;138:1114-20.

Calvo MS, Babu US, Garthoff LH, Woods TO, Dreher M, Hill G, Nagaraja, S. Vitamin D2 from light-exposed edible mushrooms is safe, bioavailable and effectively supports bone growth in rats. Osteoporosis Intl 2013;24:197-207.

Lamberg-Allardt CJ, Outila TA, Kärkkäinen MU, Rita HJ, Valsta LM. Vitamin D deficiency and bone health in healthy adults in Finland: could this be a concern in other parts of Europe? J Bone Miner Res 2001;16:2066-73.

Berg AH, Powe CE, Evans MK, Wenger J, Ortiz G, Zonderman AB, Suntharalingam P, Lucchesi K, Powe NR, Karumanchi SA, Thadhani RI. 24,25dihydroxyvitamin D3 and vitamin D status of community-dwelling black and white Americans. Clin Chem 2015;61:877-84.

Cashman KD, Hayes A, Galvin K, Merkel J, Jones G, Kaufmann M, et al. Significance of serum 24,25-dihydroxyvitamin D in the assessment of vitamin D status: A double-edged sword? Clin Chem 2015;61:636-45.

Outila TA, Mattila PH, Piironen VI, Lamberg-Allardt CJ. Bioavailability of vitamin D from wild edible mushrooms (Cantharellus tubaeformis) as measured with a human bioassay. Am J Clin Nutr 1999;69:98-8. 

25-hydroxyvitamin D: a randomized controlled trial. Eur J Clin Nutr 2011;65:965-71. calcium balance and bone growth in young rats fed normal or low calcium diet. Horm Res 2004;61:293-9. and FGF23. Annu Rev Med 2010;61:91-104. Vitamin D depletion induces RANKL-mediated osteoclastogenesis and bone loss in a rodent model. J Bone Miner Res 2008;23:1789-97.

Chun RF, Hernandez I, Pereira R, Swinkles L, Hujis T, Zhou R, et al. Differential responses to vitamin D2 and vitamin D3 are associated with variations in free 25hydroxyvitamin D. Endocrinology 2016;157:3420-30.

Powe CE, Evans MK, Wenger J, Zondeman AB, Berg AH, Nalls M, et al. Vitamin D-binding protein and vitamin D status of black Americans and white Americans. N Engl J Med 2013;369:1991-2000.

Johnsen MS, Grimnes G, Figenschau Y, Torjesen PA, Almås B, Jorde R. Serum free and bio-available 25-hydroxyvitamin D correlate better with bone density than serum total 25 hydroxyvitamin D. Scand J Clin Lab Invest 2014;74:177-83. Binkley N, Borchardt G, Siglinsky E, Krueger D. Does vitamin D metabolite measurement help predict 25(OH)D change following vitamin D supplementation? Endocrine Pract 2017;23:432-41.

Bergwitz C, Jüppner H, Regulation of phosphate homeostasis by PTH, vitamin D 


\section{Figure captions}

572

573 Figure 1. Biomarkers and bone parameters in the treatment groups: A serum 25-

574 hydroxyvitamin D (S-25(OH)D), B serum 24,25-dihydroxyvitamin D (S-24,25(OH)D $),$ C

$57524,25(\mathrm{OH}) \mathrm{D}_{2}$ to $25(\mathrm{OH}) \mathrm{D}$ ratio, $\mathbf{D}$ bone mineral content, $\mathbf{E}$ bone area, $\mathbf{F}$ bone mineral density,

576 G serum phosphate (S-Pi), H serum parathyroid hormone (S-PTH), and I serum calcium (S-

$577 \mathrm{Ca}$ ). Values are means $\pm \mathrm{SE}$, adjusted for rat body weight. $\mathrm{P}$ value in the figure is for the whole

578 test, analysis of covariance. Symbols show significant difference in the post hoc comparison

579 (least significant difference, $\mathrm{P}<0.05$ ) between the treatment groups and a: control, b:

$580 \mathrm{D}_{3}$ supplement $300 \mathrm{IU} / \mathrm{d}$, c: $\mathrm{D}_{3}$ supplement $600 \mathrm{IU} / \mathrm{d}, \mathrm{d}: \mathrm{D}_{2}$ supplement $300 \mathrm{IU} / \mathrm{d}$, e:

$581 \mathrm{D}_{2}$ supplement $600 \mathrm{IU} / \mathrm{d}$, f: intact yeast cell $300 \mathrm{IU} / \mathrm{d}$, g: intact yeast cell $600 \mathrm{IU} / \mathrm{d}$, h: yeast cell

582 wall $300 \mathrm{IU} / \mathrm{d}$, i: yeast cell wall $600 \mathrm{IU} / \mathrm{d}$. $\mathrm{n}=6$ per treatment group, except $\mathrm{n}=5$ for $\mathrm{S}$ -

$58324,25(\mathrm{OH}) \mathrm{D}_{2}$ and $24,25(\mathrm{OH}) \mathrm{D}_{2}$ to $25(\mathrm{OH}) \mathrm{D}$ ratio.

584

585

586

587

588

589

590

591

592

593

594 
Table 1 - Ingredient composition of the diets fed to rats ( $\mathrm{g} / \mathrm{kg}$ diet)

\begin{tabular}{|c|c|c|c|c|c|c|c|c|c|}
\hline $\begin{array}{l}\text { Treatment group and the estimated daily } \\
\text { vitamin D dose }\end{array}$ & $\begin{array}{l}\text { Control }\left(D_{3}\right. \\
\text { supplement) } \\
25 \text { IU/d }\end{array}$ & $\begin{array}{l}D_{3} \\
\text { supplement } \\
\mathbf{3 0 0} \text { IU/d } \\
\end{array}$ & $\begin{array}{l}D_{3} \\
\text { supplement } \\
600 \text { IU/d }\end{array}$ & $\begin{array}{l}D_{2} \\
\text { supplement } \\
300 \text { IU/d }\end{array}$ & $\begin{array}{l}D_{2} \\
\text { supplement } \\
600 \text { IU/d }\end{array}$ & $\begin{array}{l}\text { Intact } \\
\text { yeast cell } \\
300 \mathrm{IU} / \mathrm{d}\end{array}$ & $\begin{array}{l}\text { Intact } \\
\text { yeast cell } \\
600 \mathrm{IU} / \mathrm{d}\end{array}$ & $\begin{array}{l}\text { Yeast } \\
\text { cell wall } \\
\mathbf{3 0 0} \text { IU/d }\end{array}$ & $\begin{array}{l}\text { Yeast } \\
\text { cell wall } \\
600 \mathrm{IU} / \mathrm{d}\end{array}$ \\
\hline Form of vitamin D & $\mathrm{D}_{3}$ & $\mathrm{D}_{3}$ & $\mathrm{D}_{3}$ & $\mathrm{D}_{2}$ & $\mathrm{D}_{2}$ & $\mathrm{D}_{2}$ & $\mathrm{D}_{2}$ & $\mathrm{D}_{2}$ & $\mathrm{D}_{2}$ \\
\hline Amount of vitamin $D$ in the diet $(\mathrm{g} / \mathrm{kg})$ & 0.000025 & 0.000375 & 0.00075 & 0.000375 & 0.00075 & 0.000375 & 0.00075 & 0.000375 & 0.00075 \\
\hline \multicolumn{10}{|l|}{ Ingredients $(\mathrm{g} / \mathrm{kg})$} \\
\hline Casein, "Vitamin-Free" Test & 200 & 200 & 200 & 200 & 200 & 200 & 200 & 200 & 200 \\
\hline L-Cystine & 3 & 3 & 3 & 3 & 3 & 3 & 3 & 3 & 3 \\
\hline Corn Starch & 397.486 & 397.206 & 396.906 & 397.131 & 396.756 & 396.551 & 395.596 & 397.236 & 396.966 \\
\hline Sucrose & 99.822 & 99.822 & 99.822 & 99.822 & 99.822 & 99.822 & 99.822 & 99.822 & 99.822 \\
\hline Maltodextrin & 132 & 132 & 132 & 132 & 132 & 132 & 132 & 132 & 132 \\
\hline Cellulose & 50 & 50 & 50 & 50 & 50 & 50 & 50 & 50 & 50 \\
\hline Soybean Oil & 70 & 70 & 70 & 70 & 70 & 70 & 70 & 70 & 70 \\
\hline Mineral Mix, AIN-93G-MX (94046) & 35 & 35 & 35 & 35 & 35 & 35 & 35 & 35 & 35 \\
\hline Vitamin Mix, AIN-93 w/o A, D, E (120379) & 10 & 10 & 10 & 10 & 10 & 10 & 10 & 10 & 10 \\
\hline Vitamin A Palmitate $(500,000 \mathrm{IU} / \mathrm{g})$ & 0.008 & 0.008 & 0.008 & 0.008 & 0.008 & 0.008 & 0.008 & 0.008 & 0.008 \\
\hline Vitamin E, DL-alpha tocopheryl acetate $(500 \mathrm{IU} / \mathrm{g})$ & 0.15 & 0.15 & 0.15 & 0.15 & 0.15 & 0.15 & 0.15 & 0.15 & 0.15 \\
\hline Choline Bitartrate & 2.5 & 2.5 & 2.5 & 2.5 & 2.5 & 2.5 & 2.5 & 2.5 & 2.5 \\
\hline TBHQ, antioxidant & 0.014 & 0.014 & 0.014 & 0.014 & 0.014 & 0.014 & 0.014 & 0.014 & 0.014 \\
\hline Vitamin $\mathrm{D}_{2}$, ergocalciferol $(40,000 \mathrm{IU} / \mathrm{g})$ & - & - & - & 0.375 & 0.75 & - & - & - & - \\
\hline Vitamin $D_{2}$ intact yeast cell $(15,700 \mathrm{IU} / \mathrm{g})$ & - & - & - & - & - & 0.955 & 1.91 & - & - \\
\hline Vitamin $\mathrm{D}_{2}$ yeast cell wall $(55,400 \mathrm{IU} / \mathrm{g})$ & - & - & - & - & - & - & - & 0.27 & 0.54 \\
\hline $\begin{array}{l}\text { sitamin } D_{3} \text {, cholecalciterol ( } 00,000 \mathrm{lU} / \mathrm{g} \text { in } \\
\text { sucrose) }\end{array}$ & 0.02 & 0.3 & 0.6 & - & - & - & - & - & - \\
\hline
\end{tabular}

All diets: protein $18.3 \%$, carbohydrate $60.1 \%$, fat $7.0 \%$ by weight. Energy $3.8 \mathrm{Kcal} / \mathrm{g}$. 


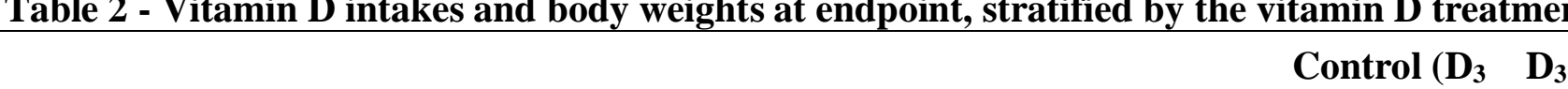

20 IU/d

Actual vitamin D intake (IU/d) $)^{\text {b }}$

Actual vitamin D intake $(\mu \mathrm{g} / \mathrm{d})^{\mathrm{b}}$

Rat body weight $(\mathbf{g})^{c}$

${ }^{\mathrm{a}} \mathrm{P}$ value from one-way analysis of variance.

${ }^{\mathrm{b}}$ Values are group means calculated based on feed consumption, data no

available for individual rats.

${ }^{c}$ Values are means \pm SD

na not applicable (the data available per treatment group, not for individual rats).

$\mathrm{n}=6$ for each group.
$\mathbf{D}_{3}$

S00 IU/d

$\mathbf{D}_{2}$

supplement

$\mathbf{D}_{2}$

Intact

Intact

Yeast cell

wall

$300 \mathrm{IU} / \mathrm{d}$

$600 \mathrm{IU} / \mathrm{d}$

$300 \mathrm{IU} / \mathrm{d}$

Yea
wall
600

wall

$600 \mathrm{IU} / \mathrm{d}$

$\mathbf{P}$

$14-204$

412

205

458

213

412

213

439

11.0 na

$262 \pm 5 \quad 263 \pm 16$

$253 \pm 39$

$262 \pm 29$

$273 \pm 18$

$273 \pm 20$

$267 \pm 25$

$262 \pm 25$

$270 \pm 15$

0.317



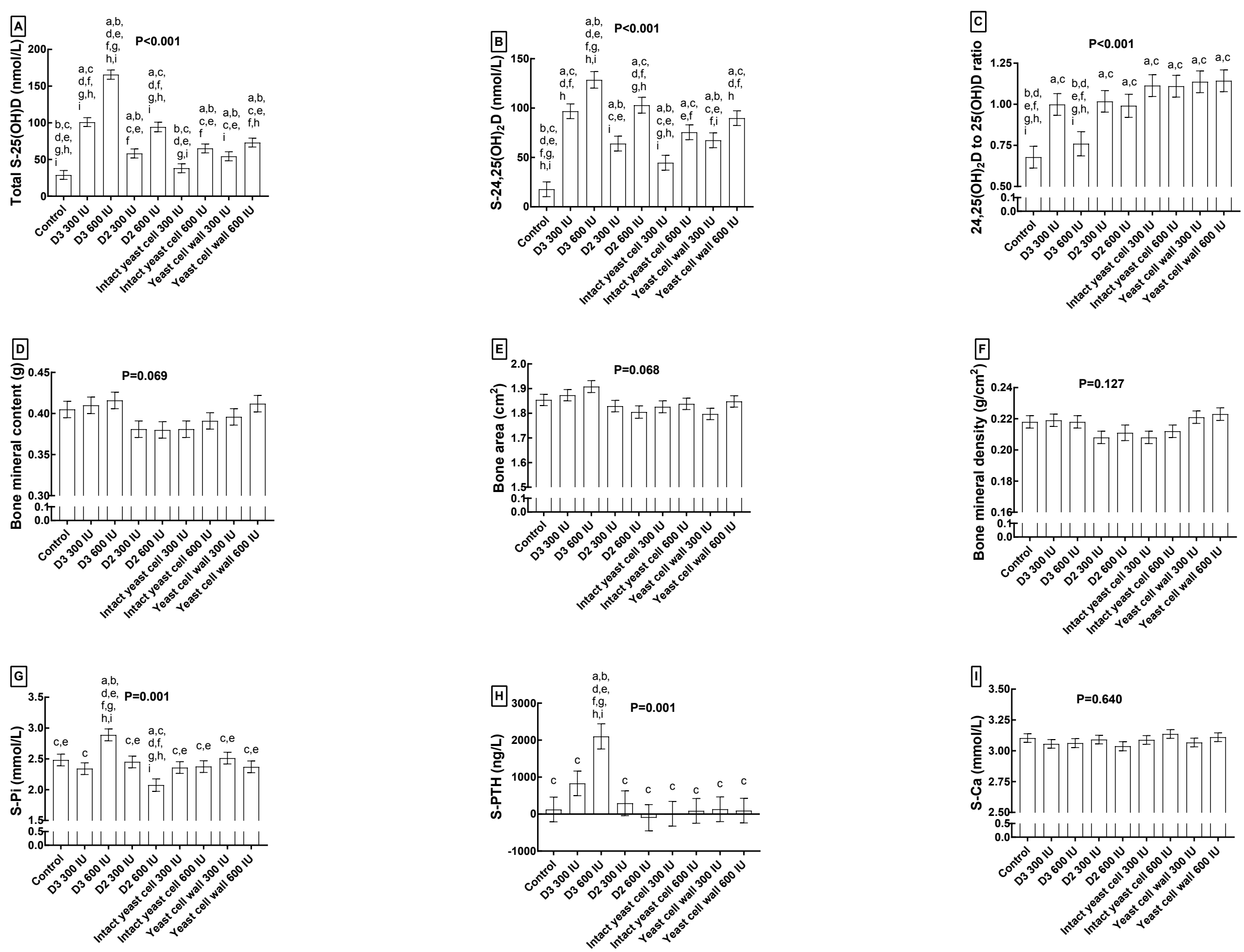